\title{
Antibodies to Human HSP60 in Patients with Juvenile Chronic Arthritis, Diabetes Mellitus, and Cystic Fibrosis
}

\author{
E. R. DE GRAEFF-MEEDER, G. T. RIJKERS, M. M. VOORHORST-OGINK. W. KUIS
} R. VAN DER ZEE, W. VAN EDEN. AND B. J. M. ZEGERS

\begin{abstract}
Department of Immunolog.' /E.R.d.G.-M., G.T.R., M.M.I.-O.. W.K., B.J.M.Z./. University Hospital for ('hildren and Youth "Het Wilhelmina Kinderziekenhuis." Utrecht. The Netherlands and Institute of Infectiotus Discases and Immunology /R.v.d.Z., W'v.E.J. Faculty of Veterinary Medicine. University' of Utrecht. The Netherlands
\end{abstract}

\begin{abstract}
The 60-kD heat shock protein (hsp60) has been implicated in the etiology and pathogenesis of both experimental and naturally occurring autoimmune diseases such as juvenile chronic arthritis (JCA). Human hsp60 is expressed in inflamed synovial tissue, and $T$ lymphocytes both from peripheral blood and synovial fluid show reactivity to human hsp60. Because the anti-hsp60 B lymphocyte response has been less well studied, we have determined the occurrence of IgG anti-human hsp60 antibodies in patients with JCA and various other autoimmune diseases of childhood. Serum IgG anti-human hsp60 antibodies in JCA patients were significantly higher compared with control children (358 and $163 \mathrm{U} / \mathrm{mL}$, respectively). Within the group of JCA patients, the highest antibody titers were found in the subgroup with a polyarticular onset of JCA. IgG anti-human hsp60 antibody levels in synovial fluid were 3- to 4-fold higher compared with paired serum samples. Because this difference was not found for total IgG or for irrelevant antibodies (anti-polyribosylribitol phosphate), this suggests local anti-hsp60 antibody production in the synovial compartment. The occurrence of anti-hsp60 antibodies is not specific for JCA but also is found in children with systemic lupus erythematosus and in cystic fibrosis, whereas mixed connective tissue disease and insulin-dependent diabetes are negative in this respect. Whether the anti-human hsp60 antibodies are directed toward species-specific sequences or to conserved sequences of the hsp60 molecule remains to be determined. (Pediatr Res 34: 424-428, 1993)
\end{abstract}

\section{Abbreviations}

hsp60, 60-kD heat shock protein IDDM, insulin-dependent diabetes mellitus

JCA, juvenile chronic arthritis

OA, oligoarticular onset

PA, polyarticular onset

SO, systemic onset

PRP, polyribosylribitol phosphate

hsp, heat shock protein

RA, rheumatoid arthritis

$\mathrm{SF}$, synovial fluid

NOD, nonobese diabetic mice

CF, cystic fibrosis

SLE, systemic lupus erythematosus

MCTD, mixed connective tissue disease

ANA, antinuclear antibody

Received December 30, 1992; accepted May 17, 1993

correspondence and reprint requests: E. R. de Graeff-Meeder. University Hospital for Children and Youth, P.O. Box 18009, 3501 CA Utrecht. The Netherlands.
The family of hsp comprises a set of proteins that serve important functions in maintenance of intracellular integrity under stressful conditions such as increased temperatures (1). Hsp are found both in prokaryotic and eukaryotic organisms, including humans, and show an extremely high amino acid sequence homology throughout phylogeny $(2,3)$. Despite the considerable degree of sequence homology between bacterial and human hsp, hsp are immunodominant antigens in a variety of bacterial infections $(4,5)$. Furthermore, a large body of experimental data published over the last decade now provides compelling evidence that hsp constitute the link between infectious diseases and autoimmunity. In experimental animal models of autoimmune diseases. notably adjuvant arthritis in rats and IDDM in NOD mice. T-cell reactivity against hsp60 has been shown to be causally associated with development of autoimmunity (6). Also, in humans there are indications that hsp, in particular hsp60, play a role in autoimmune diseases such as JCA and to a lesser degree also RA. In arthritic synovial tissue of patients with RA or JCA, hsp60 is expressed in synovial lining cells, in endothelial cells of blood vessels, and in macrophages $(7,8)$. Moreover, $T$ cells derived from SF of RA patients can be readily activated with mycobacterial hsp60 (9-11): in JCA patients this also can be achieved with recombinant human hsp60 (12).

Whereas $\mathrm{T}$-cell reactivity to human hsp60 thus clearly has been demonstrated in JCA patients, the anti-human hsp B-cell response has not yet been investigated extensively. Antibodies to microbial hsp60, hsp70, or both are detectable in various autoimmune diseases of adulthood (13-17). Antibodies to mycobacterial hsp65 have been detected in patients with JCA (18). No reports, however, are available on the occurrence of antibodies to human hsp60 in JCA. Using recombinant human hsp60, we therefore have determined IgG anti-human hsp60 antibodies in patients with JCA, as well as in various other autoimmune diseases of childhood, and in patients with CF.

\section{MATERIALS AND METHODS}

The study included 21 patients ( 12 females and nine males) with JCA as defined by the criteria of the European League Against Rheumatism (19). Four patients had an OA-JCA, 11 had a PA-JCA, and six had a SO-JCA. We tested a total of 114 serum samples for anti-human hsp60 reactivity. The age of the patients at the onset ranged from 3.8 to 18.8 y (mean $10.8 \mathrm{y}$ ). The mean duration of the disease by entry of the study was 4.8 y (Table 1). The mean follow-up was 1.8 y (1.0 to 2.8 y). Six patients were rheumatoid factor positive as determined by Waaler-Rose and latex agglutination. Eleven of the patients had ANA as determined by immunofluorescence on Hep- 2 cells. None of the patients was HLA-B27 positive. The geometric mean 
Table 1. Patient characteristics*

\begin{tabular}{|c|c|c|c|c|}
\hline & No. & Age (y) & $\begin{array}{c}\text { Duration of } \\
\text { disease }(y)\end{array}$ & Serum $\operatorname{IgG}(\mathrm{g} / \mathrm{L})$ \\
\hline $\mathrm{JCA}$ & 21 & $10.8(3.8-18.8)$ & $4.8(0.5-18.8)$ & $12.5(5.4-27.9)$ \\
\hline SLE & 11 & $12.9(8.6-17.3)$ & $4.9(0.1-10.3)$ & $12.6(4.4-37.9)$ \\
\hline MCTD & 22 & $21.7(11.2-25.8)$ & $9.9(2.4-16.4)$ & $15.9(10.2-26.6) \dagger$ \\
\hline Dermatomyositis & 4 & $8.5(7.4-11.4)$ & $3.1(1.3-4.2)$ & $11.5(9.7-15.3)$ \\
\hline CF & 24 & $12.6(1.8-20.3)$ & $9.8(0-18.8)$ & $18.0(6.3-29.0) \dagger$ \\
\hline IDDM & 33 & $11.6(3.5-16.9)$ & $6.8(1.1-12.3)$ & $8.8(4.7-22.1)$ \\
\hline Healthy & 17 & $3.7(0.4-11.6)$ & & $8.9(4.0-14.8)$ \\
\hline
\end{tabular}

* Values in parentheses are means.

+ Significantly $(p<0.05)$ higher than other patient groups and healthy controls.

serum level of $\mathrm{IgG}$ of the whole group of JCA patients was 13.9 $\mathrm{g} / \mathrm{L}$ (range, $5.4-30.8 \mathrm{~g} / \mathrm{L}$ ). The geometric mean serum level of IgG at the entry of the study was $12.5 \mathrm{~g} / \mathrm{L}$ (range, $5.4-27.9 \mathrm{~g} / \mathrm{L}$ ) and at the end was $12.5 \mathrm{~g} / \mathrm{L}$ (range, 5.4-30.8 g/L). The mean score of arthritis activity was not different between the beginning and the end of the study (1.3 versus 1.2$)$. Activity of the arthritis was scored on formal joint assessments (swelling and/or tenderness, pain, and limitation of motion): 0 , no signs of arthritis; 1 , mild arthritis; 2 , moderate arthritis; and 3, severe arthritis. The mean score of functional class was similar at the start and at the end $(2.0$ versus 1.9$)$. The functional class was assessed according to Steinbrocker et al. (20).

From six JCA patients (four with PA-JCA, two with SO-JCA), a total of eight SF samples were analyzed for the presence of $\mathrm{IgG}$ anti-hsp60 antibodies. All SF samples were obtained during an active phase of the arthritis. The age of the patients from which $\mathrm{SF}$ was obtained as well as their mean duration of disease, arthritis score, functional class, and serum IgG did not differ ignificantly from that of the group of JCA patients as a whole. The geometric mean IgG level in the SF was $8.6 \mathrm{~g} / \mathrm{L}$ (range, 2.6$15.5 \mathrm{~g} / \mathrm{L})$.

Thirty-eight sera of 11 patients (nine females and two males) with SLE defined by the criteria of the American Rheumatism Association (21), 22 patients (18 females and four males) with uvenile onset MCTD defined by the criteria of Kasukawa et al. 22), four patients (all females) with juvenile dermatomyositis lefined by Bohan et al. (23), 33 patients with IDDM, and 24 Jatients with $C F$ also were included in the study. Sera from 17 jealthy children, of which 12 have been referred to the outpatient lepartment for evaluation of possible food allergy, served as ;ontrols. All children were vaccinated with the diphtheria, tetauus, cellular pertussis, poliomyelitis vaccine at $3,4,5$, and 11 no of age (24). The full-length human hsp60 gene was kindly Jrovided by Dr. R. A. Young (Whitehead Institute, Cambridge, MA) as a phage $\lambda$ gt 11 clone isolated from a human cDNA ibrary prepared from HeLa cells by Dr. R. S. Gupta et al. (2). In $S p h I$ restriction site was introduced through intermediate ,Ex2-derived plasmids and subcloned into pRH901 [constructed rom expression vector pNGS20(+) (25)]. Subcloning of the luman hsp60 gene into pRH901 thus resulted in plasmid pRH 1011 from which the hsp60 gene product could be expressed vith isopropyl- $\beta$-D-thiogalactopyranoside induction. The hsp60 vas purified by $\left(\mathrm{NH}_{4}\right)_{2} \mathrm{SO}_{4}$ precipitation and reversed-phase IPLC as described before (12). The product of pRH901 was iubjected to the same purification procedures and was used as pecificity control.

All serum samples were stored at $-80^{\circ} \mathrm{C}$ until use. IgG antiodies to human hsp60 were measured by ELISA. To that end, nicrotiter plates (Greiner-Labortechnik, Langenthal, Germany) vere coated directly with human hsp60 [HPLC purified recomjinant hsp60 (12)] or with the purified pRH901 product, both it a concentration of $2 \mu \mathrm{g} / \mathrm{mL}$ in PBS at $37^{\circ} \mathrm{C}$ during $16 \mathrm{~h}$. For letection of $\mathrm{IgG}$ antibodies against PRP, the capsular polysacharide of Haemophilus influenzae type b. plates were coated vith $5 \mu \mathrm{g} / \mathrm{mL}$ tyraminated PRP (26). Subsequently, the coated plates were washed three times with $0.05 \%$ (vol/vol) Tween-20 in PBS and incubated for $1 \mathrm{~h}$ at $37^{\circ} \mathrm{C}$ with $1 \%(\mathrm{wt} / \mathrm{vol}) \mathrm{BSA}$ in PBS. Thereafter, the plates were washed again. After incubation with serial dilutions of serum samples in diluting buffer (PBS, $0.05 \%$ ( $\mathrm{vol} / \mathrm{vol}$ ) Tween-20,0.5\% BSA) for $2 \mathrm{~h}$ at $37^{\circ} \mathrm{C}$, the plates were washed again and incubated with peroxidase labeled rabbit anti-human IgG (Dako, Glostrup, Denmark). The plates were washed again and finally incubated with $0.1 \mathrm{mg} / \mathrm{mL}$ tetramethylbenzidine dihydrochloride (Sigma Chemical Co., St. Louis, $\mathrm{MO}$ ) in $0.05 \mathrm{M}$ phosphate-citrate buffer with $0.03 \%$ sodium perborate (Sigma). After an incubation of 15 to $30 \mathrm{~min}$. the reaction was stopped by adding $1 \mathrm{M} \mathrm{H}_{2} \mathrm{SO}_{4}$ and absorbance at $450 \mathrm{~nm}$ was read on an ELISA Titertek Multiscan Spectrophotometer (Flow, Irvine, UK). All antibody titers are expressed relative to a high titered anti-human hsp60 serum, which was assigned $1000 \mathrm{U} / \mathrm{mL}$. This standard serum was withdrawn from a patient with OA-JCA with active arthritis. An anti-PRP hyperimmune serum containing $32.5 \mu \mathrm{g} / \mathrm{mL}$ antibody (27) was used as a standard in the anti-PRP assays.

The IgG anti-human hsp60 antibody concentration in the reference serum was estimated by comparing the OD evident from the binding with a human hsp60-coated ELISA plate with the OD of the same serum, captured on an anti-IgG-coated ELISA plate. The plates were incubated with alkaline phosphatase-conjugated anti-IgG and developed with $1 \mathrm{mg} / \mathrm{mL}$ paranitrophenylphosphate (Sigma) in diethanolamine buffer $\mathrm{pH} 9.8$. After 30 to $60 \mathrm{~min}$ incubation at room temperature, the reaction was stopped by $2.4 \mathrm{M} \mathrm{NaOH}$, and absorbance was read at 405 $\mathrm{nm}$. This procedure resulted in an estimated antibody concentration of approximately $1 \mu \mathrm{g} \mathrm{IgG}$ anti-human $\mathrm{hsp} 60 / \mathrm{mL}$ in the reference serum.

The average IgG anti-human hsp60 antibody levels are expressed as geometric means. In statistical tests for the individual patient, the mean of all follow-up data was used. For comparison of the location of various groups of data, a Kruskal-Wallis test was performed because of skewed data. To calculate correlations, c.g. serum IgG and IgG anti-human hsp60 antibody levels, a Spearman rank correlation test was performed because of skewed data.

\section{RESULTS}

The availability of recombinant hsp60 enabled the quantitation of IgG anti-human hsp60 antibodies in sera of juvenile patients with various autoimmune diseases. In the majority of serum samples, OD values obtained on plates coated with the product of pRH901 were below $5 \%$ of that obtained on human hsp60 coated plates. In five samples (including four from JCA patients) out of 261 tested, the OD values on pRH901-coated plates were higher than that on human hsp60-coated plates; these samples were excluded from further analysis. When more than two samples of an individual patient were available, the geometric mean of all follow-up data was used in statistical analysis. From a series of 21 patients with JCA, a total of 114 serum samples were obtained. The number of samples per patient 
ranged from three to seven; the interval over which serum samples were collected ranged from 1 to $3 \mathrm{yr}$. In patients with $\mathrm{JCA}$, geometric mean serum IgG anti-human hsp60 antibody levels were significantly higher than in control children (358 and $163 \mathrm{U} / \mathrm{mL}$, respectively; $p<0.05$; Fig. 1).

IgG anti-human hsp60 antibodies also were detectable in all SF samples analyzed (geometric mean, $1463 \mathrm{U} / \mathrm{mL}$; range, $315-$ $3274 \mathrm{U} / \mathrm{mL}$ ). In six of eight cases, the level of $\mathrm{IgG}$ anti-human hsp60 antibodies was even higher in SF than in matched serum samples. A significant correlation was found between the level of IgG anti-human hsp60 in serum and SF (Fig. 2$)\left(r^{2}=0.707\right.$; $p=0.017)$. Because these data suggest local IgG anti-hsp60 antibody production by SF B lymphocytes, we determined levels of IgG antibodies against an irrelevant polysaccharide antigen. PRP, in the same set of matched serum and SF samples. Serum IgG anti-PRP antibody levels were higher as in SF; there was no correlation between the level of anti-hsp60 and anti-PRP antibodies (Fig. 2).

The occurrence of high serum IgG anti-human hsp60 antibody concentrations was not restricted to JCA but was also found in four of 11 patients with SLE. The geometric mean of IgG antihuman hsp60 antibodies of all SLE patients was $650 \mathrm{U} / \mathrm{mL}$ (range, 59-3677 U/mL; Fig. 3), being significantly higher in SLE patients than in healthy controls $(p<0.05)$. In 21 of 22 patients with juvenile MCTD and four of four with juvenile dermatomyositis, serum IgG anti-human hsp60 antibodies were not significantly different from healthy control children [geometric mean for MCTD patients, $241 \mathrm{U} / \mathrm{mL}$ (range, 34-990 U/mL) and for juvenile dermatomyositis patients, $75 \mathrm{U} / \mathrm{mL}$ (range, 26-

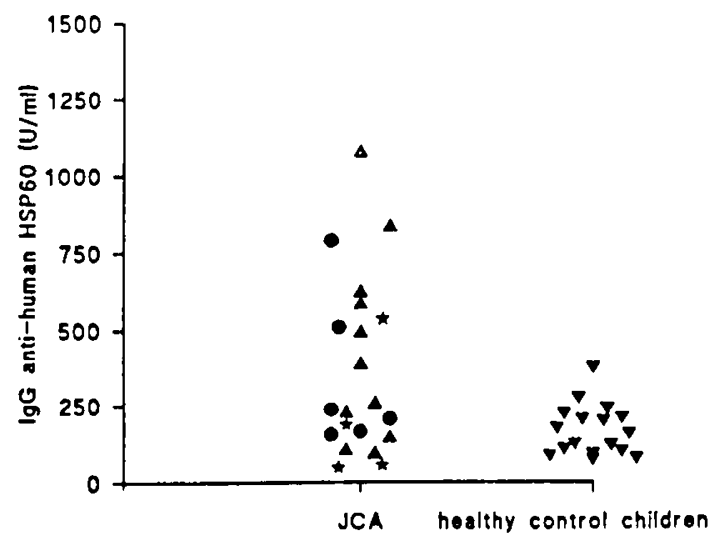

Fig. 1. Geometric mean values of ELISA IgG anti-human hsp60 antibodies in JCA patients and controls. Different symbols represent the subtype of JCA: triangle, polyarticular onset; circle, systemic onset: and stars, oligoarticular onset of JCA.
$137 \mathrm{U} / \mathrm{mL}$ ), Fig. 3]. In comparison with healthy controls, serum IgG anti-human hsp60 antibodies of patients with IDDM were not significantly different (geometric mean, $172 \mathrm{U} / \mathrm{mL}$ : range, 30-474 U/mL; Fig. 3). There was no difference in the levels of IgG anti-human hsp60 between recent-onset IDDM patients $(<2$ $\mathrm{yr}$ after onset) and those with longer disease duration [(geometric means, $100 \mathrm{U} / \mathrm{mL}$ (range, 30-396 U/mL) and $119 \mathrm{U} / \mathrm{mL}$ (range. $33-474 \mathrm{U} / \mathrm{mL}$ ), respectively; $p=0.7442)$ ]. For the total group of IDDM patients, there was no correlation between duration of the disease and IgG anti-human hsp60 titer $\left(r^{2}=0.00134 ; p=\right.$ 0.52 ). Levels of serum IgG anti-human hsp60 antibodies in patients with $C F$ were significantly higher than those of healthy controls [geometric mean of $\mathrm{CF}$ patients, $1052 \mathrm{U} / \mathrm{mL}$ (range, 196-3317 U/mL) and that for healthy controls, $163 \mathrm{U} / \mathrm{mL}$ (range, 78-376 U/mL); $p<0.001$; Fig. 3].

Increased serum IgG anti-human hsp60 antibodies were not observed in all patients with JCA or SLE and, moreover, the level of $\operatorname{IgG}$ anti-hsp60 antibodies was found to vary (up to 4fold) over time within a given patient. Therefore, potential correlations of serum IgG anti-human hsp60 antibody titer with age of the patients, JCA subtype, the presence of ANA and RF, duration of disease, arthritis score, functional class, and serum IgG concentrations were analyzed by Spearman rank correlation test. For the group of JCA patients and SLE patients, we observed a correlation between the level of IgG anti-human hsp60 antibodies and serum IgG level $(r=0.69, p<0.05$ and $r=0.85, p$ $<0.002$ respectively). This latter correlation is statistically significant for the PA-JCA and SO-JCA subgroup $(r=0.79, p<0.05$ and $r=0.73, p<0.05$, respectively) and not for the OA-JCA group. For the other evaluated items including arthritis score and functional class, no correlation was found.

The highest levels of IgG anti-human hsp60 antibodies were found in the PA-JCA patients. Five of the six patients with SOJCA and three of four patients with OA-JCA had serum IgG anti-human hsp60 antibody levels within the range of normal control children. The one patient with SO-JCA and high serum IgG anti-human hsp60 antibodies differed from the other SOJCA patients in that a proven mycobacterial infection existed. In this patient, a correlation was found between arthritis activity and level of IgG anti-human hsp60 antibodies (Fig. 4).

\section{DISCUSSION}

In this study, we investigated the occurrence of IgG antihuman hsp60 antibodies in patients with JCA and various other autoimmune diseases, patients with $\mathrm{CF}$ and healthy control children.

In patients with JCA, a significant higher level of IgG antihuman hsp60 antibodies was found compared with healthy controls. The group of PA-JCA did account for the highest level
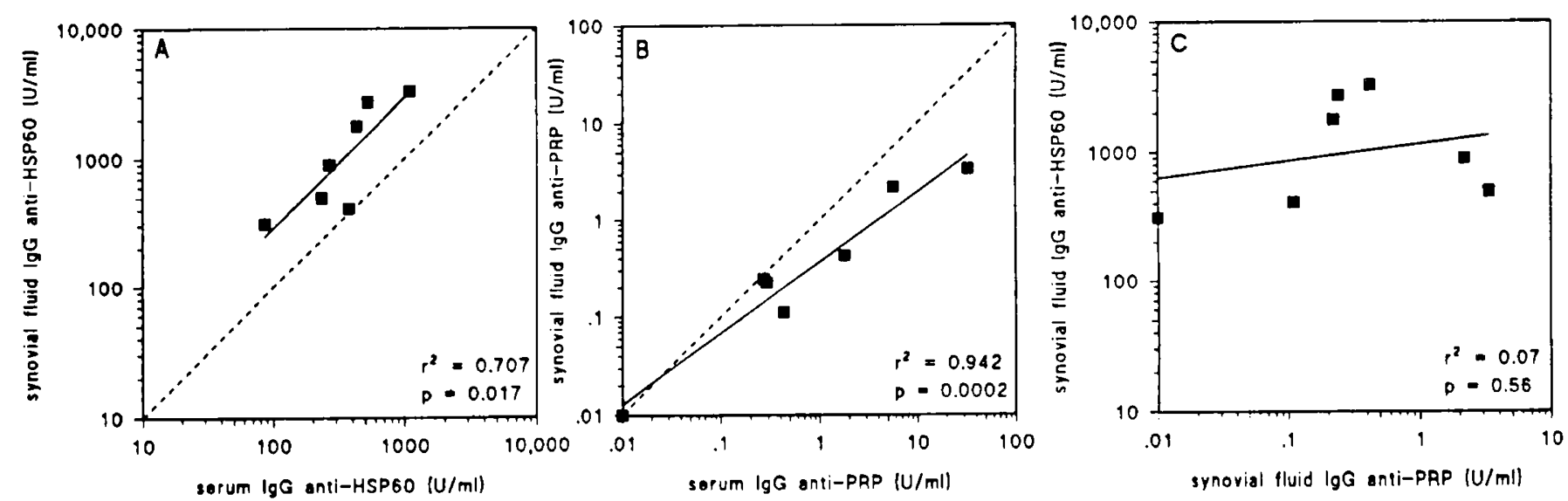

Fig. 2. Correlation between IgG anti-human hsp60 (left panel) and IgG anti-PRP (middle panel) matched pairs of serum and SF samples. Right panel shows absence of correlation between IgG anti-hsp60 and IgG anti-PRP in SF samples. 


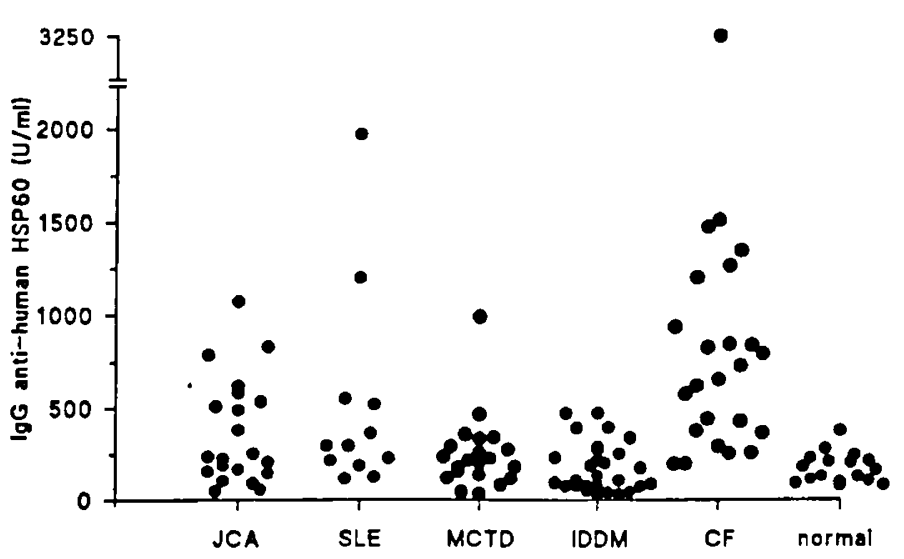

Fig. 3. Geometric mean values of ELISA IgG anti-human hsp60 antibodies in patients with JCA, SLE, MCTD. IDDM, CF, and normal control children.

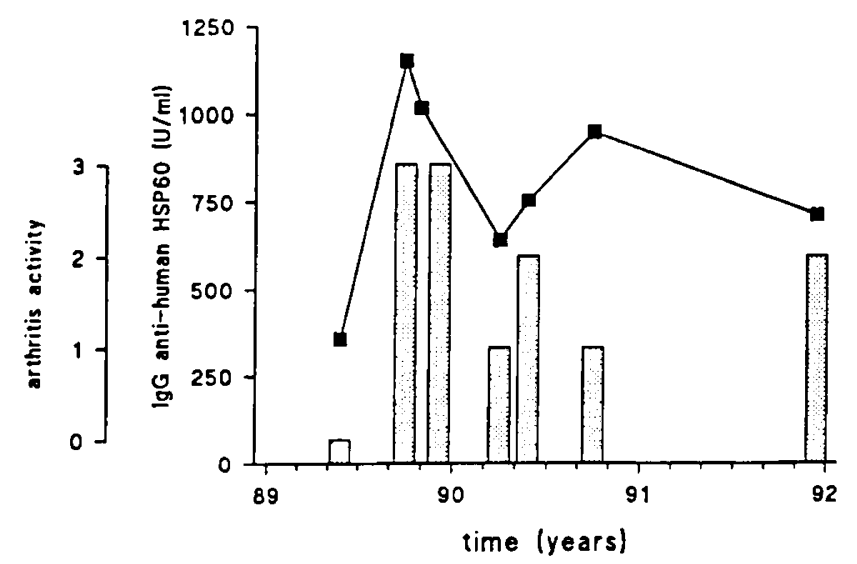

Fig. 4. Correlation in time between arthritis activity and level of $\mathrm{IgG}$ anti-human hsp60 antibodies in a patient with a systemic onset of JCA and a proven mycobacterial infection. Square symbols, IgG anti-human hsp60 antibody levels; dotted bars, arthritis activity.

of IgG anti-human hsp60 antibodies. In two other subtypes of JCA (OA-JCA and SO-JCA), the levels of IgG anti-human hsp60 antibodies did not differ significantly from normal children. Detailed analysis revealed in JCA patients no correlation between the level of IgG anti-human hsp60 antibodies and JCA subtype, presence of ANA or RF, duration of disease, disease activity or disablement. In particular, we found no correlation between disease activity and IgG anti-human hsp60 antibody titer. Antibodies to mycobacterial hsp65 have been found in OA-JCA and particularly during active disease (18).

We documented a significant increase of $\mathrm{IgG}$ anti-human hsp60 antibodies in comparison with healthy children in only one of the other tested autoimmune diseases: i.e. in the group of SLE patients $(p<0.05)$. The highest levels of IgG anti-human hsp60 antibodies were documented in the group of CF patients. It should be noted that $\mathrm{CF}$ patients are exposed chronically to high levels of bacterial antigens, including bacterial hsp.

Data from literature show that in nearly all sera from adult patients with RA, SLE, MCTD, Sjögren syndrome, and Reiter's disease but also in normal controls, antibodies to (human) hsp60 can be detected (17). Furthermore, antibodies to bacterial hsp60 and hsp70 are reported in these autoimmune diseases also (13$15,28)$. Apart from methodologic differences, the specificity of these antibodies (real autoantibodies to human hsp or antibacterial hsp antibodies) remains to be assessed.

Based on clinical arguments, JCA is considered a T-cell mediated autoimmune disease. Reasons in favor of this concept are the clinical observations that viral infections, which can induce suppression of cellular immunity, may lead to remission of disease activity (29-31). In patients with primary B-cell disorders (e.g. common variable immunodeficiency, agammaglobulinemia), chronic arthritis indistinguishable from that occurring in B-cell competent patients with JCA has been documented ( 32 . 33). In patients with primary T-cell disorders (e.g. severe combined immunodeficiency), chronic arthritis has not been observed. In healthy humans, naturally acquired anti-human hsp60 antibodies will be present. The above suggests that the B-cell compartment is not primarily involved in the development of JCA. A role of anti-human hsp 60 antibodies in the pathogenesis of JCA therefore seems unlikely.

High concentrations of IgG anti-human hsp antibodies were found in SF of patients with JCA. Total IgG levels and IgG antiPRP antibodies in SF were not higher as in serum, suggesting the local production of anti-hsp60 antibodies. Whereas these antibodies probably do not directly contribute to the pathogenesis of JCA for reasons outlined above, they may modulate the T-lymphocyte response to hsp60. The uptake and processing by monocytes/macrophages may be facilitated when hsp60 is complexed with anti-hsp antibodies.

From studies in experimental animals, it has become clear that next to adjuvant arthritis $(34,35)$ the spontaneous development of diabetes mellitus in so-called NOD mice also is causally associated with autoimmunity to hsp $60(36,37)$. This association has not yet gained experimental support for diabetes mellitus in humans. In patients with IDDM, no increase in serum IgG antihuman hsp60 could be documented (Fig. 3). Serum of NOD mice with diabetes has been shown to contain hsp60 (36). If this would hold true for IDDM patients also, anti-hsp antibodies could be present complexed with hsp60, causing false-negative results in this group of patients.

For patients with JCA and SLE but not for patients with CF, a correlation has been observed between the level of serum IgG and IgG anti-human hsp60 antibodies. Presently, the significance of this phenomenon is unclear. The fact that in patients with $\mathrm{CF}$ and in patients of one subtype of JCA (OA-JCA) such a correlation has not been observed argues against the explanation that a polyclonal B-cell activation as such is the underlying mechanism for this correlation. Furthermore, in other juvenile autoimmune disease such as MCTD, dermatomyositis, and IDDM, a correlation between serum IgG and IgG anti-human hsp60 antibodies also was not observed.

In this study, we have determined IgG antibodies that bind to recombinant human hsp60. Because of the high degree of amino acid homology between human and bacterial hsp60, it cannot be concluded directly whether these antibodies are true autoantibodies or whether they are directed against sequences shared by human and bacterial hsp60. In this respect, it should be noted that immunization of mice with cellular pertussis vaccine does induce anti-hsp60 antibodies that cross-react with semipurified human hsp60 from HeLa cell mitochondria (38). Routine vaccination with diphtheria, tetanus, cellular pertussis, poliomyelitis vaccine containing cellular pertussis induces antibodies that cross-react with bacterial hsp60 but also with human hsp60. IgG anti-human hsp60 antibody levels attained are within the range of that observed in our healthy control group (39). It can be concluded that the presence of IgG anti-human hsp60 antibodies reflects in vivo exposure to bacterial and/or human hsp. Clearly, further analysis, including binding studies with synthetic peptides encompassing human specific sequences and conserved sequences, will be required to resolve this issue.

Acknowledgments. The authors thank Dr. J. van der Laag for providing the sera of the CF patients; Dr. C. C. E. de Jong-de Vos van Steenwijk for the sera of the IDDM patients; and Drs. H. A. W. M. Tiddens, Th. J. W. Fiselier, D. J. de Rooij, W. H. J. van Luijk, R. Herzberger-ten Cate, L. W. A. van SuilijlekomSmit, and W. J. van Venrooij for providing the sera of the juvenile onset MCTD patients. I. van der Tweel, Department of Biostatistics, Utrecht University School of Medicine, is acknowl- 
edged for advice on statistical analysis and Dr. A. B. J. Prakken for help with statistical analysis.

\section{REFERENCES}

1. Ellis RJ 1990 The molecular chaperone concept. Semin Cell Biol 1:1-25

2. Jindal S, Dudani AK, Harley CB, Singh B, Gupta RS 1989 Primary structure of a human mitochondrial protein homologous to bacterial and plant chaperonins and to $65 \mathrm{kD}$ mycobacterial antigen. Mol Cell Biol 9:2279-2283

3. Lamb JR, Young DB 1990 T cell recognition of stress proteins. A link between infectious and autoimmune disease. Mol Biol Med 7:311-321

4. Young DB 1990 Stress proteins and the immune response. Antonie Van Leeuwenhoek 58:203-208

5. Young DB 1991 Stress protein as antigens during infection. In: Rice Evans C, Winrow V, Blake D, Burdon R (eds) Stress Proteins and Inflammation. Richelieu Press, London

6. Cohen IR 1991 Autoimmunity to chaperonins in the pathogenesis of arthritis and diabetes. Annu Rev Immunol 9:567-589

7. Karlsson Parra A. Dimeny E. Fellstrom B. Klareskog L 1989 HIV receptors (CD4 antigen) in normal human glomerular cells. N Engl J Med 320:741

8. Boog CJP, de Graeff-Meeder ER, Lucassen MA, van der Zee R, VoorhorstOgink MM, van Kooten PJS, Geuze HJ, van Eden W 1992 Two monoclonal antibodies generated against human hsp60 show reactivity with synovia membranes of patients with juvenile chronic arthritis. J Exp Med 175:18051810

9. Holoshitz J, Klajman A, Drucker I, Lapidot Z, Yaretzky A, Frenkel A, van Eden W, Cohen IR 1986 T-lymphocytes of rheumatoid arthritis patients show augmented reactivity with a fraction of mycobacteria cross-reactive with cartilage. Lancet 2:305-309

10. Pope RM. Pahlavani MA, LaCour E. Sambol S. Desai BV 1989 Antigenic specificity of rheumatoid synovial fluid lymphocytes. Arthritis Rheum 32:1371-1375

11. Res PC, Schaar CG, Breedveld FC, van Eden W, van Embden JDA, Cohen IR, de Vries RRP 1988 Synovial fluid $T$ cell reactivity against $65 \mathrm{kD}$ heat shock protein of mycobacteria in early chronic arthritis. Lancet 2:478-480

12. de Graeff-Meeder ER, van der Zee R, Rijkers GT, Schuurman H-J, Kuis W Bijlsma JWJ, Zegers BJM, van Eden W 1991 Recognition of human $60 \mathrm{kD}$ heat shock protein by mononuclear cells from patients with juvenile chronic arthritis. Lancet 337:1368-1372

13. Bahr GM, Rook GA, al Saffar M, van Embden J, Stanford JL, Behbehani K 1988 An analysis of antibody levels to mycobacteria in relation to HLA type: evidence for non-HLA-linked high levels of antibody to the $65 \mathrm{kD}$ heat shock protein of $\mathrm{M}$. bovis in rheumatoid arthritis. Clin Exp Immunol $74: 211-215$

14. Tsoulfa G, Rook GA, Bahr GM, Sattar MA, Behbehani K, Young DB, Mehlert A, van Embden JD. Isenberg DA. Hay FC, Lydyard DM 1989 Elevated IgG antibody levels to the mycobacterial $65-\mathrm{kDa}$ heat shock protein are characteristic of patients with rheumatoid arthritis. Scand J Immunol 30:519-527

15. Tsoulfa G, Rook GA, van Embden JD, Young DB, Mehlert A, Isenberg DA. Hay FC. Lydyard PM 1988 Raised serum $\operatorname{lgG}$ and IgA antibodies to mycobacterial antigens in rheumatoid arthritis. Ann Rheum Dis 48:118123

16. McLean L. Winrow V, Blake D 1990 Role of immunity to mycobacterial stress proteins in rheumatoid arthritis. J Exp Pathol (Oxford) 71:295-303

17. Winfield JB, Jarjour W 1991 Do stress proteins play a role in arthritis and autoimmunity? Immunol Rev 121:193-220

18. Danieli MG, Markovits D, Gabrielli A. Corvetta A. Giorgi PL, van der Zee R. van Embden JD, Danieli G, Cohen IR 1992 Juvenile rheumatoid arthritis patients manifest immune reactivity to the mycobacterial $65-\mathrm{kDa}$ heat shock protein, to its $180-188$ peptide, and to a partially homologous peptide of the proteoglycan link protein. Clin Immunol Immunopathol 64:121-128

19. Wood PHN 1978 Special meeting on nomenclature and classification of arthritis in children. In: Munthe E (ed) The Care of Rheumatic Children. Eular Publishers, Basel. Switzerland, pp 47-50

20. Steinbrocker O. Traeger CH, Batterman RC 1949 Therapeutic criteria in rheumatoid arthritis. JAMA 140:659-662

21. Tan EM, Cohen AS, Fries JF 1982 The 1982 revised criteria for the classification of systemic lupus erythematosus. Arthritis Rheum 25:1276-1277

22. Kasukawa R, Tojo T, Miyawaki S, Yoshida H, Nobunaga M, Suzuki T, Takasaki T, Tamura T 1987 Preliminary diagnostic criteria for classification of mixed connective tissue disease. Exerpta Medica International Congress Series 719:41-47

23. Bohan A, Peter JB. Bowman RL 1977 A computer assisted analysis of 153 patients with polymyositis and dermatomyositis. Medicine 56:255-286

24. Rumke HC 1989 Evaluation of the National Vaccination Program. Ned Tijdschr Geneeskd 133:866-868

25. Stoker NG, Grant KA, Dockrell HM, Howard CR, Jouy NF, McAdam KPWJ 1989 High level expression of genes cloned in phage lambda-gf 11 . Gene 78:93-99

26. Robbins JB, Parke JC. Schneerson R, Whisnant JK 1973 Quantitative measurement of natural and immunization induced Haemophilus influenzae type b capsular antibodies. Pediatr Res 7:103-110

27. Siber GR, Ambrosino DM, McIver J. Ervin TJ. Schiffman G, Sallan S, Grady GF 1984 Preparation of human hyperimmune globulin to Haemophilus influenzae $b$. Streptococcus pnetumoniae and Neisseria meningitidis. Infect Immun 45:248-254

28. McLean IL, Archer JR, Cawley MI, Pegley FS. Kidd BL. Thompson PW 1990 Specific antibody response to the mycobacterial $65 \mathrm{kDa}$ stress protein in ankylosing spondylitis and rheumatoid arthritis. Br J Rheumatol 29:426429

29. Yoshioka K. Miyata H. Maki S 1981 Transient remission of juvenile rheumatoid arthritis after measles. Acta Paediatr Scand 70:419-420

30. Simpanen E, von Essen R. Isomaki H 1977 Remission of juvenile rheumatoid arthritis (Still's disease) after measles. Lancet 2:987-988

31. Still GF 1978 On a form of chronic joint disease in children. Am J Dis Child 132:192-200

32. McLaughlin JF, Schaller J, Wedgwood RJ 1972 Arthritis and immunodeficiency. J Pediatr 81:801-803

33. Good RA. Rotstein J 1960 Rheumatoid arthritis and agammaglobulinemia. Bull Rheum Dis 10:203-208

34. van Eden W 1990 Heat-shock proteins in autoimmune arthritis: a critical contribution based on the adjuvant arthritis model. APMIS 98:383-394

35. van Eden W 1991 Heat-shock proteins and the immune system. Immunol Rev 121:5-28

36. Elias D. Markovits D. Reshef T, Zee R, Cohen IR 1990 Induction and therapy of autoimmune diabetes in non-obese diabetic (NOD/Lt) mouse by a $65-\mathrm{kD}$ heat shock protein. Proc Natl Acad Sci USA 87:1576-1580

37. Elias D, Reshef T. Birk OS, van der Zee R. Walker MD. Cohen IR 1991 Vaccination against autoimmune mouse diabetes with a T-cell epitope of the human 65-kDa heat shock protein. Proc Natl Acad Sci USA 88:30883091

38. Burns DL. Gould-Kostka JL. Kessel M, Arciniega JL 1991 Purification and immunological characterization of a GroEl-like protein from Bordetella pertussis. Infect Immun 59:1417-1422

39. del Giudice G, Gervaix A. Costantino P. Wyler C-A. Tougne C. de GraeffMeeder ER, van Embden J, van der Zee R. Nencioni L. Rappuoli R, Suter S, Lambert P-H 1993 Priming to heat shock proteins in infants vaccinated against Pertussis. J Immunol 150:2025-2032 